\title{
Is There a Correlation Between Organizational Features and Digital Communication Usage?
}

\author{
Article history: \\ Received:2 February 2016 \\ Sent for revision: 11 March 2016 \\ Received in revised form: 30 June 2016 \\ Accepted: 11 July 2016 \\ Available online: 8 October 2016
}

\begin{abstract}
Digitalization, networking and information sharing have brought to the paradigm shifts in both business and marketing communication. Extant scholarly and practical studies emphasize the importance of digital communication tools and activities, and explore new opportunities for organizations. Unlike previous studies, this study is not solely focused on the usage, but rather on the examination and determination of differences in the usage of digital communication in organizations of various characteristics such as size, industry, business maturity and geographical coverage. A transversal empirical study was conducted in the Republic of Serbia, on a randomly selected sample of 231 private and publicly owned organizations companies, institutions and banks. The results indicate that the statistical difference in the usage of digital communication tools and activities by organization types exists, whereby the intensity of correlation differs depending on the organizational feature and digital communication tool or activity.
\end{abstract}

Keywords: digital communication, digital tools, digital activities, organizational features.

\section{Da li postoji korelacija između karakteristika organizacije i korišćenja digitalnih komunikacija?}

Apstrakt: Digitalizacija, povezivanje $i$ deljenje informacija doveli su do promena u poslovanju i praksi marketinških komunikacija. Naučne i praktične

\footnotetext{
${ }^{1}$ Victoria Group, tamara.veselinovic.m@gmail.com

${ }^{2}$ Faculty of Organizational Sciences, University of Belgrade

${ }^{3}$ Faculty of Organizational Sciences, University of Belgrade 
Veselinović T. et al.: Is There a Correlation Between Organizational Features and...

studije objašanjavaju i naglašavaju značaj instrumenata $i$ aktivnosti digitalnih komunikacija, kao i mogućnosti koje pružaju organizacijama. Za razliku od prethodnih studija, ova studija nije samo fokusirana na korišćenje, već na ispitivanje $i$ utvrđivanje razlika $u$ korišćenju digitalnih komunikacija $u$ organizacijama različitih karakteristika, kao što su veličina, delatnost, dužina $i$ geografska pokrivenost poslovanja. U radu je predstavljena empirijska studija sprovedena u Republici Srbiji, na slučajno izabranom uzorku od 231 organizacije, u privatnom i državnom vlasništvu - preduzeća, institucije $i$ banke. Rezultati istraživanja pokazuju da postoji statistički značajna razlika u upotrebi instrumenata i aktivnosti digitalnih komunikacija u različitim tipovima organizacija, a da se intenzitet veze razlikuje u zavisnosti od karakteristike organizacije $i$ instrumenta ili aktivnosti koje se posmatraju.

Ključne reči: digitalne komunikacije, instrumenti digitalnih komunikacija, aktivnosti digitalnih komunikacija, karakteristike organizacije.

\section{Introduction}

The possibilities offered by the Internet technologies, its mass applications and penetration to all areas of human life, followed by a rapid development of social media and mobile technologies have had a large impact not only in a way that we communicate (Maresh-Fuehrer \& Smith, 2016), but also in a way we do business (Dong \& Wu, 2015). Digital media have intensified a number of interactions and relationships, alleviated connections and allowed us to more easily integrate to different communities (Kietzmann, Hermkens, McCarthy \& Silvestre, 2011). Nowadays, the customer journey is different. This is due to the fact that customers spend a lot of time online, gathering information on products/services, communicating with other consumers and very often requiring a direct relationship with organizations and brands (HallPhillips, Park, Chung, Anaza \& Rathod, 2016; Hudson, Huang, Roth \& Madden, 2016). This communication can be initiated through different digital channels from any location at any time (Yadav, Joshib \& Rahmanc, 2015). It caused the change in marketing communication in the way that digital communication became its integral part.

Definitely, the digitalization, networking and sharing of information transformed marketing communication into a different set of tools and activities for connecting brands and consumers (Mulhern, 2009). Although the advantages of the digital communication usage are clear and obvious, academics and practitioners are not unanimous in defining this term, and still there is no a theoretical consensus on a final list of the tools and activities of digital communication. Generally, the authors agree that digital tools help organizations in reaching out the target audience in a timely manner and at 
Veselinović $T$. et al.: Is There a Correlation Between Organizational Features and...

the right location providing them with more personalized content which is based on their needs (Chan \& Yazdanifard, 2014).

Academics' and practitioners' interest for the usage of digital communication in business and its benefits has been growing both globally (Georgescu \& Popescul, 2015; Stelzner, 2014; Technorati Media, 2013; Breakendrige, 2012; Halligan \& Shah 2010; Fox, 2010; Kaplan \& Haenlein, 2010; Weber, 2009; Evans, 2008) and in Serbia (Bauer, 2013; Čokorilo \& Terzić, 2013; Sudarević, 2011; Đukić, 2011; Lalić, 2010). The results of these studies emphasize the importance of using digital communication tools and activities and opportunities they create for business.

However, the extant studies both on the global (Stelzner, 2015; Barnes \& Lescault, 2014) and national level (Statistical Office of the Republic of Serbia, 2015; Executive Group, 2013; MASMI, 2012) do not examine the nexus between the specific organizational features (size, industry, business maturity and geographical coverage), and the usage of digital communication tools and activities. Unlike previous studies, this study examines not only the level of usage, but focuses on exploring and determining the differences in the usage of digital communication in different organization types.

The paper is organized as follows. Section 2 reviews the literature from the field of digital communication and provides the theoretical background. This section particularly emphasizes the digital communication tools and activities which are included in the survey. Section 3 presents the results of surveys on digital communication usage that had been already conducted in Serbia. Section 4 introduces the methodology used in the study. Section 5 contains the results of the study and discussion. Section 6 presents concluding remarks and managerial implications.

\section{Literature review}

Companies have been using the World Wide Web, tools such as email, direct marketing and informational websites, to present the information about themselves and/or their products to a broad audience (Tiago \& Verissimo, 2014). The same authors suggest that the main shift in the communication strategy happened with the emergence of social media which enabled companies to interact and develop relations with their customers.

Traditional communication channels limit the message to a given medium, at a given moment and in a limited space, based on an interruption model (Godin, 1999). If consumers were to pay any attention to the message, they would have to interrupt their ongoing activities. On the other side, web marketing is based on delivering useful content at the right time, when a 
Veselinović T. et al.: Is There a Correlation Between Organizational Features and...

consumer really needs it (Scott, 2009). The upside of Internet, compared to the conventional media, is its multi-media character - the transmission of not only text and graphics, but audio and video content as well (Latinović, Jotanović, Jauševac \& Majkić, 2007).

According to Chaffey, Ellis-Chadwick, Mayer and Johnston (2006) companies have to select the appropriate online and offline marketing communication techniques in order to maximize visitors to a website, and to acquire new customers online. In their opinion, online communication techniques include Search engine marketing, Online PR, Online partnerships, Interactive advertising, E-mail marketing, Viral marketing, and on-site promotional techniques as well. Emergence of social media have driven an additional communication channel which Mangold and Faulds (2009) call a new hybrid element of the promotion mix.

On the basis of the literature review, the authors of this paper for the purpose of the study considered digital communication tools to be: Website, Facebook, Twitter, YouTube, Blogs, Linkedln, Social Networking Sites (SNSs) for photo sharing. On the other side, the digital communication activities that the authors of this paper examined include: e-mail marketing, mobile marketing, online sales and online advertising.

Internet can be used for creating relations through three strategies (Anderson \& Kerr, 2002): informing customers, getting information from customers and online sales. Organizations may use various digital communication tools and activities for the implementation of these strategies.

Website as a basic web communication tool enables promotion, overview of products/services, sales, customer support and informing (Tate, 2010). Its effectiveness depends on the architecture and design, as well as the usefulness and credibility of its content (Thomas, 2011; Carroll, 2010).

A blog is a type of website where the content marked with dates is presented in reversed chronological order (Herring, Scheidt, Bonus \& Wright, 2004). Posts can vary from the link with the short explanation through a paragraph to a whole essay (Weil, 2006). Organizations have been gradually accepting blogs as a marketing tool, recognizing the fact that it can efficiently and economically create a two-way conversations and ongoing interactions (Balagué \& de Valck, 2013) and be used as an instrument managing online reputation (Cho \& Huh, 2007).

With growing popularity of social media, companies are actively engaging consumers through social media, so that they can actively participate and engage in group activities and networked communities contributing to a symbolic tie between the consumer and the company (Bagozzi, Bergami, Marzocchi \& Morandin, 2012). 
Veselinović $T$. et al.: Is There a Correlation Between Organizational Features and...

Social media employ modern software tools and applications to create a new dimension of communication among users (Okanović, Milosavljević, Cicvarić Kostić \& Vlastelica Bakić, 2013). Kietzmann et al. (2011) suggest that the new realm of social media relates to the interactive platforms via which individuals and communities share, co-create, discuss, and modify user-generated content. Therefore, social media allow people to connect and communicate, and also to create interrelations using the sites for social networking (Safko \& Brake, 2009).

According to Lincoln (2009), social media can be viewed as online tools and platforms used by people in order to share their attitudes, believes, experiences and perspectives. These new media are used for winning the affection and trust of users, and encouraging them to be more active.

Social media offer organizations various possibilities for improving and expanding their relations with consumers. Bauer (2013) particularly encompasses following possibilities: targeted brand creation, improvement of partnering relations by sharing information, advanced research, development through the permanent cooperation and open communication. Among impacts that social media have on business, Georgescu and Popescul (2015) state the increase of business information capital. Participants in the "Social Media Marketing Industry Report 2015" survey listed the following as the benefits of social media marketing: increased exposure, increased traffic, developed loyal fans, provided marketplace insight, generated leads, improved search rankings, grown business partnerships, established thought leadership, improved sales and reduced marketing expenses.

Ellis-Chadwick and Doherty (2012) elaborate on importance of permission email marketing campaigns for building and maintaining relationships with consumers. They should be permission-based and employ various tactics of

format, address, subject lines, hyperlinks and interactivity in order to attract attention and provoke further interest when it comes to e-mail marketing. Furthermore, Berman (2016) emphasizes the importance of mobile marketing as a part of promotional strategy, and he identifies three strategic advantages of mobile marketing, from the fact that mobile marketing devices are always connected, over the ability to generate location-sensitive offers, to the ability to send relevant personalized messages and offers. A combination of mobile marketing with other channels can improve the effects of overall communication (Hussain, 2009).

Several studies, aiming to examine the level of digital communication tools and activities usage, have already been conducted, both globally and in Serbia. The annual Social Media Examiner survey "Social Media Marketing Industry Report 2015" (Stelzner, 2015) questioned 3,700 marketers in January 2015 about their social media marketing and how they use it to grow 
Veselinović $T$. et al.: Is There a Correlation Between Organizational Features and...

their business. In the sample, $52 \%$ of marketers were from US, $20 \%$ from UK, Canada and Australia, and the rest from other countries worldwide. Results showed that $96 \%$ of marketers are participating in social media marketing. Out of that, $93 \%$ is using Facebook, 79\% Twitter, 71\% Linkedln, 55\% YouTube, and in photo sharing SNS $45 \%$ is using Pinterest and $36 \%$ Instagram.

The survey of the use of social media among the largest American corporations from the Fortune 500 list in 2014 has shown the following (Barnes \& Lescault, 2014): Linkedln is universally most often used social media within the Fortune 500 corporations (used by $97 \%$ ); the other two most commonly used social media are Twitter $83 \%$ and Facebook $80 \%$, followed by YouTube (67\%), Pinterest (36\%), blog (31\%) and Instagram (20\%).

\section{Surveys on digital communication usage in Serbia}

When it comes to the surveys from the field of digital communication conducted in Serbia, Statistical Office of the Republic of Serbia conducted a survey in April 2015 "The Use of Information-Communication Technologies in the Republic of Serbia". They used telephone aided interview and questioned 1,261 companies. The target group consisted of companies with 10 and more employees from the Republic of Serbia (without Kosovo and Metohija). The sample was stratified based on the size (small 10-49, medium 50-249, large $250+$ ), industry and location of companies. The results showed that in 2014 out of $99.1 \%$ of companies that had internet access, $75.2 \%$ of companies had a website. Segmented by the size, $92.9 \%$ of large companies, $88.0 \%$ of medium sized, and $71.2 \%$ of small sized companies had the website. Results also indicated that only $22.9 \%$ of companies accepted offers (except email offers) through internet (14.6\% large, $21.8 \%$ medium and $23.6 \%$ small companies), and $28.1 \%$ of company advertised via internet. Regarding the use of social networks, $28.6 \%$ stated that they use them, suggesting Facebook, Linkedln, Xing, Yammer, whereas $10 \%$ stated that they use multimedia sites for the content sharing (YouTube, Flickr, Picassa), and 8.8\% blog-Twitter.

The Executive Group agency conducted research during December 2012 and January 2013, aiming to investigate trends and tendencies in the use of social media in corporate communication in Serbia. This research examined over 100 companies, mainly those operating in the field of marketing. Respondents stated that social media are highly important for their business, and five most important tools were: Facebook, online advertising, YouTube, Twitter and blog. 
Veselinović T. et al.: Is There a Correlation Between Organizational Features and...

Similar research was conducted by the Masmi Company in June 2012. The research aimed to explore the usage of social media for business purposes in Serbia and examined 170 companies operating in Serbia. Around 35\% of them use social media on a daily basis, while around $44 \%$ on a weekly basis or less frequently. Serbian companies most often use Facebook as a social media, (nearly 90\%), while the other social media are significantly less present (YouTube, Twitter, Linkedln- around 50\%).

These studies offer insight of the different digital communication tools and activities usage. However, neither one of them examines weather nor how do different characteristics of companies affect the use of digital communication tools and activities. Also, these studies were mainly focused on social media usage. In order to define clear managerial implications for the most effective usage of digital communication tools and activities, the authors of this paper believe that there is a need to determine the correlation between the level of usage of all digital tools and activities and organizational features.

\section{Research Methodology}

A transversal empirical study examined the usage of digital communication in organizations with different features in the Republic of Serbia. The aims of this paper are:

- To examine the level of usage of digital communication tools and activities in organizations,

-To examine and determine the difference in the usage of digital communication in organizations with different features (size, industry, business maturity, geographical coverage).

The research was based on primary data and employed questionnaire as a research tool using both paper-and-pencil (questionnaires filled in written were given to the authors in direct contact) and computer assisted approaches (electronic version of questionnaire was distributed via e-mail).

The questionnaire was distributed in the period July-December 2014 on a randomly selected sample of 300 private and publicly owned organizations (companies, institutions and banks) in Serbia, of which 250 agreed to participate and 231 returned valid questionnaires. Companies were chosen from the "Biznis Top", the rankings of the most successful Serbian companies, according to the turnover and profit, published by magazine "Biznis \& Finansije". Banks were chosen from the "Finansije Top", the rankings of the most successful banks, insurance companies, brokerage companies, private investment and pension funds and auditing companies, based on official financial analyses and analyses of each sector, published by magazine 
Veselinović $T$. et al.: Is There a Correlation Between Organizational Features and...

"Biznis \& Finansije" as well. Institutions were selected from the administrative register on the website of the Statistical Office of the Republic of Serbia. The study was focused on managers of different managerial levels. The precondition was that they were familiar with the digital communication in their organization. The aims and purposes of the study were firstly explained to all examinees that participated in the study and their involvement was on a voluntary basis.

The research presented in this paper is a part of a larger study conducted for the purpose of the doctoral dissertation (Veselinović, 2015).

The questionnaire for this study consisted of two sets of questions. The first set examined the independent variables - the features of organizations: size, industry, business maturity and geographical coverage. The second set examined the dependent variable - the level of usage of digital communication in organizations. According to the level of usage and importance, respondents were asked to rate the following:

- Digital communication tools: Website, Facebook, Twitter, YouTube, Blogs, Linkedln, Social Network Sites (SNSs) for photo sharing (Pinterest, Instagram),

- Digital communication activities: E-mail marketing, Mobile marketing, Online sales, Online advertising.

Respondents were asked to answer multiple choice questions on a five-point Likert-type scale, where ' 1 ' stands for 'does not use at all' and ' 5 ' stands for "dominant tool or activity" in the overall communication mix of organization. The scale and purpose of research were firstly explained to the respondents.

In the examined sample the size of an organization was measured using the number of employees. Therefore, the sample encompassed $19 \%$ of organizations with less than 10 employees (micro-organizations), $20.3 \%$ of organizations with 11 to 50 employees (small organizations), $23.4 \%$ of organizations with 51 to 250 employees (medium sized organizations), and $37.2 \%$ of organizations with more than 251 employees (large organizations).

In the sample, 51 organizations or $22.1 \%$ were manufacturing companies; 150 organizations or $64.9 \%$ were in the service business, and $30(13.0 \%)$ organizations were both in manufacturing and service sectors.

The sample encompassed $17.7 \%$ of organizations operating up to five years, $40.3 \%$ operating 6 to 15 years, $10 \%$ operating from 16 to 25 years, $21.6 \%$ operating from 26 to 35 years and $21.6 \%$ of organizations operating for more than 35 years.

Respondents were asked to determine a geographical coverage of their organizations. The sample included $26.0 \%$ of organizations operating on a 
Veselinović T. et al.: Is There a Correlation Between Organizational Features and...

local level, $16 \%$ on a national level, $37 \%$ on a regional level, and $42 \%$ of organizations were multinational.

The examined organizations sample structure is presented in Table 1.

Table1. Sample structure

\begin{tabular}{|l|c|c|}
\hline Organization features & Absolute frequency & Relative frequency \\
\hline Size & 44 & 19.0 \\
\hline $\begin{array}{l}\text { Micro-organizations } \\
\text { (less than 10 employees) }\end{array}$ & 47 & 20.3 \\
\hline Small organizations (11-50 employees) & 54 & 23.4 \\
\hline $\begin{array}{l}\text { Medium sizes organizations } \\
\text { (51-251 employees) }\end{array}$ & 86 & 37.2 \\
\hline $\begin{array}{l}\text { Large organizations } \\
\text { (more than 251 employees) }\end{array}$ & \multicolumn{2}{|l|}{} \\
\hline Industry & 51 & 22.1 \\
\hline Manufacturing & 150 & 64.9 \\
\hline Services & 30 & 13.0 \\
\hline Manufacturing and services & \multicolumn{2}{|l|}{} \\
\hline Business maturity & 41 & 17.7 \\
\hline Up to 5 year & 93 & 10.3 \\
\hline From 6 to 15 years & 23 & 10.4 \\
\hline From 16 to 25 years & 24 & 21.6 \\
\hline From 26 to 35 years & 50 & 26.0 \\
\hline More than 35 years & \multicolumn{2}{|l|}{} \\
\hline Geographical coverage & 60 & 16.0 \\
\hline Local level & 37 & 16.0 \\
\hline National level & 37 & 42.0 \\
\hline Regional level & 97 & \\
\hline Multinational level &
\end{tabular}

Source: authors' calculations

\section{Results and discussion}

\subsection{Results}

More than half of sampled organizations do not use the following digital communication tools: blog (67.5\%), Twitter (58.9) and photo sharing SNSs $(54.1 \%)$, whereas online sales is not performed by $54.1 \%$ of the examined organizations. A large portion of organizations, however less than half of them, do not use YouTube (48.1\%), Linkedln (47.2\%) and do not practice mobile marketing (42.4\%).

Although these tools and activities are the least used, a number of organizations that marked them as frequently used is significant: Linkedln $33.8 \%$, Twitter $-30.7 \%$, YouTube $-28.1 \%$, photo sharing SNSs $-26 \%$, 
Veselinović T. et al.: Is There a Correlation Between Organizational Features and...

mobile marketing $-23.8 \%$, online sales $-20.3 \%$, and among them blog was marked as dominant tool only by $13.9 \%$ of organizations.

The digital communication tools dominantly used by Serbian organizations are website and Facebook. Website is intensively used by $86.6 \%$ of organizations, while only $8.2 \%$ the organization do not have its own website. Facebook is dominantly used tool as reported by $63.2 \%$ of organizations. On the other side, $10.9 \%$ of organizations do not use it intensively and $26 \%$ do not use it at all. Among the activities of digital communication, online advertising is predominant (41.5\%).

Among the digital communication tools and activities, the usage of e-mail marketing is most evenly distributed on the one to five-point scale. On one side, $19 \%$ of organizations do not practice it at all, while on the other, it is a dominant activity for $33.8 \%$ of them.

Descriptive statistics for the dependent variables is shown in Table 2.

Table 2. Descriptive statistics for the dependent variables (absolute and relative frequencies)

\begin{tabular}{|c|c|c|c|c|c|c|c|}
\hline & Digital Communication & & 1 & 2 & 3 & 4 & 5 \\
\hline \multirow{14}{*}{$\frac{\infty}{8}$} & \multirow{2}{*}{ Website } & Absolute freq. & 19 & 2 & 7 & 3 & 200 \\
\hline & & Relative freq. & 8.2 & 0.9 & 3.0 & 1.3 & 86.6 \\
\hline & \multirow{2}{*}{ Facebook } & Absolute freq. & 60 & 0 & 17 & 8 & 146 \\
\hline & & Relative freq. & 26 & 0 & 7.4 & 3.5 & 63.2 \\
\hline & \multirow{2}{*}{ Twitter } & Absolute freq. & 136 & 8 & 15 & 1 & 71 \\
\hline & & Relative freq. & 58.9 & 3.5 & 6.5 & 0.4 & 30.7 \\
\hline & \multirow{2}{*}{ YouTube } & Absolute freq. & 111 & 16 & 26 & 13 & 65 \\
\hline & & Relative freq. & 48.1 & 6.9 & 11.3 & 5.6 & 28.1 \\
\hline & \multirow{2}{*}{ Blogs } & Absolute freq. & 156 & 19 & 15 & 9 & 32 \\
\hline & & Relative freq. & 67.5 & 8.2 & 6.5 & 3.9 & 13.9 \\
\hline & \multirow{2}{*}{ Linkedln } & Absolute freq. & 109 & 19 & 12 & 13 & 78 \\
\hline & & Relative freq. & 47.2 & 8.2 & 5.2 & 5.6 & 33.8 \\
\hline & \multirow{2}{*}{ SNSs for photo sharing } & Absolute freq. & 125 & 10 & 22 & 14 & 60 \\
\hline & & Relative freq. & 54.1 & 4.3 & 9.5 & 6.1 & 26 \\
\hline \multirow{8}{*}{ 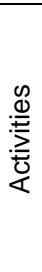 } & \multirow{2}{*}{ E-mail marketing } & Absolute freq. & 44 & 25 & 32 & 52 & 78 \\
\hline & & Relative freq. & 19 & 10.8 & 13.9 & 22.5 & 33.8 \\
\hline & \multirow{2}{*}{ Mobile marketing } & Absolute freq. & 98 & 9 & 30 & 39 & 55 \\
\hline & & Relative freq. & 42.4 & 3.9 & 13 & 16.9 & 23.8 \\
\hline & \multirow{2}{*}{ Online sales } & Absolute freq. & 128 & 9 & 20 & 27 & 47 \\
\hline & & Relative freq. & 55.4 & 3.9 & 8.7 & 11.7 & 20.3 \\
\hline & \multirow{2}{*}{ Online advertising } & Absolute freq. & 27 & 15 & 30 & 63 & 96 \\
\hline & & Relative freq. & 11.7 & 6.5 & 13 & 27.3 & 41.5 \\
\hline
\end{tabular}

Source: authors' calculations

The influence of size, industry, business maturity and geographical coverage on the level of usage of digital communication was measured using a $\chi^{2}$ (Pearson Chi-Square) test, for the given degrees of freedom (df). The study 
Veselinović T. et al.: Is There a Correlation Between Organizational Features and...

used .05 value for the statistically significant difference $(p \leq .05$ determines a statistically significant difference between two variables). The strength of correlation between variables was determined by Chramer's indicator (Chramer's V). Intensity of correlation between the variables (V) was measured using following values (Osteen \& Bright, 2010):

- $\mathrm{V}>0.5$ - strong correlation;

- V $0.3-0.5$ - mild correlation;

- V 0.1 - 0.3 - weak correlation;

- $\mathrm{V}<0.1$ - very weak correlation or no correlation at all.

Usage of digital communication in organizations of different size The sample results indicate that the size of an organization affects (Table 3 ):

Table 3. The influence of the size of organization on the usage of digital communication

\begin{tabular}{|c|c|c|c|c|c|}
\hline & \multirow{2}{*}{ Digital Communication } & \multicolumn{4}{|c|}{ Size of organization } \\
\hline & & $\chi^{2}$ & $\mathrm{Df}$ & $\mathrm{P}$ & $\mathrm{V}$ \\
\hline \multirow{7}{*}{$\begin{array}{l}\frac{\infty}{8} \\
\end{array}$} & Website & 72.622 & 12 & $0.000^{*}$ & 0.324 \\
\hline & Facebook & 14.246 & 12 & 0,114 & 0.143 \\
\hline & Twitter & 8.457 & 12 & 0.748 & 0.110 \\
\hline & YouTube & 25.509 & 12 & $0.013^{*}$ & 0.192 \\
\hline & Blogs & 31.332 & 12 & $0.002^{*}$ & 2.213 \\
\hline & Linkedln & 33.700 & 12 & $0.001^{*}$ & 0.221 \\
\hline & SNSs for photo sharing & 27.892 & 12 & $0.006^{\star}$ & 0.201 \\
\hline \multirow{4}{*}{ 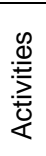 } & E-mail marketing & 14.795 & 12 & 0.253 & 0.146 \\
\hline & Mobile marketing & 37.995 & 12 & $0.000^{*}$ & 0.234 \\
\hline & Online sales & 42.209 & 12 & $0.000^{*}$ & 0.247 \\
\hline & Online advertising & 34.928 & 12 & $0.003^{*}$ & 0.225 \\
\hline
\end{tabular}

* Statistically significant difference

Source: authors' calculations

- The usage of a website $(\mathrm{Sig}=0.000<0.05)$ - the size of an organization affects the existence of a website, but the strength of this correlation is mild;

- The usage of YouTube ( $\mathrm{Sig}=0.013<0.05)$ - the size of an organization affects the use of YouTube, but the strength of this correlation is weak;

- The usage of a blog ( $\mathrm{Sig}=0.002<0.05)$ - whether an organization uses a blog as a communication tool or not, depends on the size of an organization, and the correlation between these two variables is strong;

- The usage of Linkedln (Sig=0.001<0.05) - the size of an organization affects the use of Linkedln, but the correlation is weak;

- The usage of any photo sharing SNS, Pinterest and Instagram $(\mathrm{Sig}=0.006<0.05)$ - the use of these social media depends on the size of an organizations, but the correlation is weak; 
Veselinović T. et al.: Is There a Correlation Between Organizational Features and...

- The usage of mobile marketing $(\mathrm{Sig}=0.000<0.05)$ - the size affects the practice of mobile marketing, but the correlation is weak;

- Online sales $(\mathrm{Sig}=0.000<0.05)$ - the size of an organization affects online sales, but the correlation is weak;

- Internet advertising $(\mathrm{Sig}=0.003<0.05)$ - the size of an organization determines internet advertising, but the correlation is weak.

Usage of digital communication in organizations operating in different industries

Industry affects the differences in (Table 4):

- The usage of a website $(\mathrm{Sig}=0.004<0.05)$ - use of a website is affected by the industry in which an organization operates;

- The usage of a Facebook $(\mathrm{Sig}=0.001<0.05)$ - the use of Facebook depends on the industry in which an organization operates;

- Practice of e-mail marketing $(\mathrm{Sig}=0.001<0.05)$ - the use of e-mail marketing depends on the industry in which an organization operates;

- In all of the above statements the strength of the correlation between variables is weak.

Table 4. The influence of the industry on the usage of digital communication

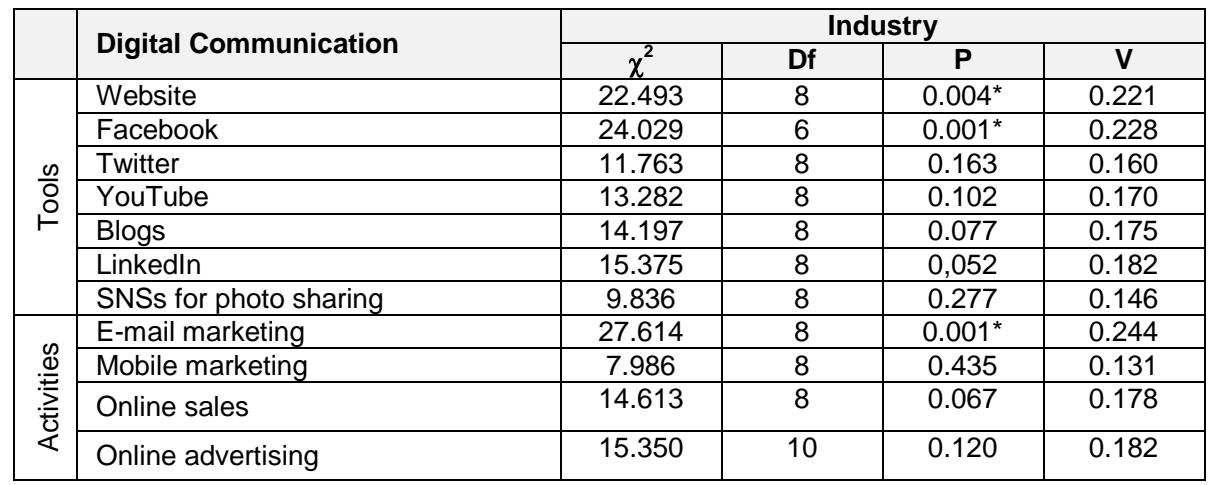

* Statistically significant difference

Source: authors' calculations

Usage of digital communication in the organizations of different business maturity

Organizations with different maturity of business differ in the usage of digital communication tools and activities, but the strength of these correlations is weak (Table 5):

- The usage of a website $(\mathrm{Sig}=0.000<0.05)$ - business maturity affects the use of a website; 
Veselinović T. et al.: Is There a Correlation Between Organizational Features and...

- The usage of Facebook $(\mathrm{Sig}=0.000<0.05)$ - business maturity significantly affects the use of Facebook;

- The usage of Twitter ( $\mathrm{Sig}=0.004<0.05)$ - the use of Twitter is influenced by the business maturity;

- The usage of YouTube (Sig=0.013<0.05) - the difference in business maturity affects the use of YouTube;

- The usage of Linkedln (Sig=0.000<0.05) - the use of Linkedln depends on the business maturity;

- The usage of SNSs for photo sharing, Pinterest and Instagram $(\mathrm{Sig}=0.000<0.05)$ - the use of these social media depends on the business maturity;

- The practice of mobile marketing $(S i g=0.046<0.05)$ - the business maturity affects the use of mobile marketing;

- Online sales $(\mathrm{Sig}=0.002<0.05)$ - the business maturity affects online sales;

- Online advertising ( $\mathrm{Sig}=0.024<0.05)$ - the business maturity affects online advertising.

Table 5. The influence of the business maturity on the usage of digital communication

\begin{tabular}{|c|c|c|c|c|c|}
\hline & \multirow{2}{*}{ Digital Communication } & \multicolumn{4}{|c|}{ Business maturity } \\
\hline & & $\chi^{2}$ & Df & $\mathbf{P}$ & $\mathbf{V}$ \\
\hline \multirow{7}{*}{$\begin{array}{l}\frac{\omega}{\circ} \\
\stackrel{\circ}{\circ}\end{array}$} & Website & 43.357 & 16 & $0.000^{*}$ & 0.217 \\
\hline & Facebook & 51.591 & 12 & $0.000^{*}$ & 0.273 \\
\hline & Twitter & 34.700 & 16 & $0.004^{*}$ & 0.194 \\
\hline & YouTube & 31.078 & 16 & $0.013^{*}$ & 0.183 \\
\hline & Blogs & 23.279 & 16 & 0.106 & 0.159 \\
\hline & Linkedln & 46.735 & 16 & $0.000^{*}$ & 0.225 \\
\hline & SNSs for photo sharing & 62.054 & 16 & $0.000^{*}$ & 0.259 \\
\hline \multirow{4}{*}{ 离 } & E-mail marketing & 26.212 & 16 & 0.051 & 0.168 \\
\hline & Mobile marketing & 26.624 & 16 & $0.046^{*}$ & 0.170 \\
\hline & Online sales & 37.405 & 16 & $0.002^{*}$ & 0.201 \\
\hline & Online advertising & 34.257 & 20 & $0.024^{*}$ & 0.193 \\
\hline
\end{tabular}

* Statistically significant difference

Source: authors' calculations

Usage of digital communication in the organizations of different geographical coverage

Organizations operating on different geographical levels differ in the usage of digital communication tools and activities, except for (Table 6):

- The statistically significant difference does not exist (Sig=0.501>0.05) among the organizations in the use of mobile marketing; 
Veselinović T. et al.: Is There a Correlation Between Organizational Features and...

- The statistically significant difference does not exist $(\mathrm{Sig}=0.395>0.05)$ among the organizations in online advertising.

As for the other digital communication tools and activities, there is a statistically significant difference regarding the geographical coverage of organization. However, this correlation is weak except in the case of Linkedln, where the correlation is mild.

Table 6. The influence of geographical coverage on the usage of digital communication

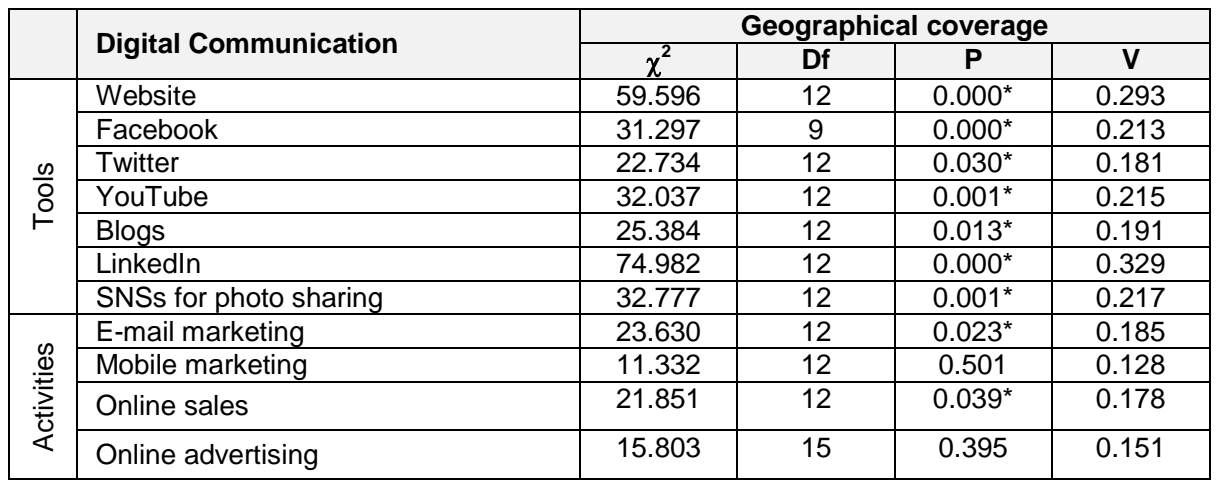

*Statistically significant difference

Source: authors' calculations

\subsection{Discussion}

The results of the empirical study in Serbia indicate that:

- A majority of organizations do not use blogs, Twitter, photo sharing SNSs, YouTube, Linkedln, online sales and mobile marketing.

- A majority of organizations use website and Facebook as dominant digital tools; whilst dominant activity is online advertising.

- The assessments of the use of e-mail marketing are most evenly distributed on the one to five-point scale, varying from not being practiced to being a dominant digital communication activity in organizations.

- The percentage of organizations that do not practice mobile marketing is very similar to the percentage of those that actively use it.

According to the Fortune 500 study (Barnes \& Lescault, 2014), a study similar to this one, the least used tools are blog and photo sharing SNSs, which can be explained with the specific characteristics of a blog as a tool of digital communication and the fact that photo sharing SNSs, such as Instagram and Pinterest, are much younger social media. However, companies from the 
Veselinović T. et al.: Is There a Correlation Between Organizational Features and...

Fortune 500 list, compared to the Serbian counterparts, more frequently use Linkedln, Twitter and YouTube, which are, together with Facebook, the most used tools. On the other side, Facebook is a dominant tool in Serbia.

As far as the correlation between the specific characteristics of organization and the usage of digital communication tools and activities is concerned, the results indicate that the size of an organization affects the difference in use of digital communication tools and activities (the difference lacks in the case of Facebook, Twitter, and e-mail marketing). However, the correlation between the variables is weak, except in the case of blog (strong correlation) and website (medium strength correlation).

Industry does not affect the difference in usage of digital communication tools and activities. A difference of weak intensity appears only for website, Facebook and e-mail marketing.

Business maturity affects the usage of digital communication tools and activities. Although statistical difference is not present only in the use of blog and e-mail marketing, in all other cases the correlation is weak.

Geographical coverage of organization affects the differences in usage of digital tools and activities. The difference is not statistically significant only in the practice of mobile marketing and online advertising. In the case of other digital communication tools and activities that showed statistically significant difference, the correlation is weak, except in the case of Linkedln where the strength of correlation is mild.

To the best of the authors' knowledge, there is no other studies examining the correlation between the specific characteristics of organization and the usage of digital communication tools and activities. Therefore, the comparison with the similar studies could only be done with results that refer to the level of digital communication usage.

\section{Conclusion}

Internet technologies, social media and mobile technologies led to important changes in the way companies operate and communicate with customers (Maresh-Fuehrer \& Smith, 2016; Dong \& Wu, 2015; Georgescu and Popescul, 2015; Bauer, 2013). The results of previous academic and practical research emphasize the importance of digital tools and activities and the opportunities they create for business. This study examined the level of usage of digital communication tools and activities in Serbian organizations, as well as differences in their use depending on the characteristics of organizations: size, industry, business maturity, geographical coverage. 
Veselinović $T$. et al.: Is There a Correlation Between Organizational Features and...

Results indicate that organizations in Serbia communicate insufficiently in the digital realm. The study has shown that even when there is a correlation between the usage of digital communication and different organization types, that correlation is most often weak in its intensity. That indicates a high level of applicability and potential benefits for business of various organizations, regardless their size, industry, business maturity and geographical coverage. The general usage of digital communication tools and activities in the organizations of different characteristics could be explained with the fact that they require significantly lower investments for their implementation compared to cost of production and media buying for traditional media, such as television, print and out-of-home.

Compared to global trends of digital communication usage in marketing communication mix, there is a room for improvement in the usage of the following tools: Twitter, YouTube, blog, Linkedln and SNS for photo sharing. As Serbian citizens mostly use Internet for the purpose of being active on social media, especially Facebook, Twitter and blogs (Statistical Office of the Republic of Serbia) companies should intensify usage of these tools for communication with consumers. Moreover, less than a half of researched companies in Serbia use YouTube, notwithstanding we globally have been faced with a growing number of people who are spending immense amounts of time on YouTube (Dehghani et al., 2016). Having in mind the fact that the most frequent users of this channel are young generation between 18 and 34 years old who impose two-thirds of YouTube and watch YouTube videos more than any cable TV channel (Perrin, 2015), for the companies that target this population, the advertising potential of YouTube is tremendous. Furthermore, organizations could benefit from broader usage of Linkedln as a platform for screening job candidates, as increasing numbers of employers on global level do (Bohnert \& Ross, 2010).

With respect to the activities, there is a clear space for further development in the field of mobile marketing and online sales. Having in mind time spent on mobile media, number of searches, and both direct and indirect mobile generated sales, Berman (2015) clearly explained strategic advantages of mobile marketing, that companies should capitalized on. Taking into account the large number of online sales benefits for both companies and consumers and its growing potential (Shaffey, 2006), companies should intensify this activity as well. Using a broad set of social media platforms and available digital communication tools and activities, managers can participate in a mutually beneficial interactions and relations with customers.

As these results reflect one period of time, further research can be based on a longitudinal study and inclusion of additional digital communication tools and activities. Further research could also examine if non-existing or weak correlation between the usage of digital communication and different 
Veselinović T. et al.: Is There a Correlation Between Organizational Features and...

organization types is due to the universal usability and applicability of digital tools and activities, or due to the facts that there is not enough differentiation in their usage. Studying the practice of digital communication and business results generated from its usage could lead to defining more specific purposes for some of digital communication tools and activities for different organizations (corporations vs. SMEs, multinationals vs. local business, wellestablished businesses vs. new companies on the market, industry A vs. industry B). That would extend the body of knowledge and contribute to the better understanding of this phenomenon.

\section{References}

Anderson, K., \& Kerr, C. (2002). Customer relationship management. New York: McGraw-Hill.

Arnold, J. (2008). E-mail marketing for dummies. New York: Wiley Publishing.

Bagozzi, R.P., Bergami, M., Marzocchi, G.L., \& Morandin, G. (2012). Customerorganization relationships: Development and test of a theory of extended identities. J Appl Psychol, 97(1), 63-76. pmid:21766998

Barnes, G.N., \& Lescault, A.M. (2014). The 2014 Fortune 500 and social media: LinkedIn dominates as use of newer tools explodes. Charlton College of Business Center for Marketing Research, University of Massachusetts Dartmouth.

Bauer, I. (2013). Digitalni marketing. Beograd: Zavod za udžbenike.

Breakendrige, D. (2012). Social media and public relations: Eight new practices for the $P R$ professional. New Jersey: Pearson Education.

Brito, M. (2012). Smart business: A playbook for social media in your organization: Social business. New York: Pearson Education.

Carroll, B. (2010). Writing for digital media. New York: Routledge.

Chaffey, D., Ellis-Chadwick, F., Mayer, R., \& Johnston, K. (2006). Internet marketing: Strategy, implementation and practice. Pearson Education Limited.

Chan, J.M., \& Yazdanifard, R. (2014). How social media marketing can influence the profitability of an online company from a consumer point of view. Journal of Research in Marketing, 2(2), 157-160.

Cho, S., \& Huh, J. (2007). Corporate blogs as a public relations tool: A content analysis applying the relational maintenance framework. In: Annual Conference of International Communication Association, San Francisco.

Čokorilo, R., \& Terzić, S. (2013). New media in public relations. Kultura, 139, 328-345.

de la Rica, E. (2006). Marketing en Internet. Madrid: Anaya.

Dong, J.Q., \& Wu, W. (2015). Business value of social media technologies: Evidence from online user innovation communities. The Journal of Strategic Information Systems, 24(2), 113-127.

Djukić, S. (2011). Uloga i značaj društvenih medija u komuniciranju vrednosti marke. Marketing, 42(1), 17-27.

Evans, D. (2008). Social media marketing: An hour a day. Indianapolis: John Willey publishing. 
Veselinović T. et al.: Is There a Correlation Between Organizational Features and...

$\begin{array}{cccc}\text {-Executive } & \text { Group. } & \text { (2013). } & \text { Retrieved }\end{array}$

Feltenstein, T. (2010). 501 killer marketing tactics to increase sales, maximize profits, and stomp your competition. New York: McGraw-Hill.

Fox, V. (2010). Marketing in the age of Google: Your online strategy is your business strategy. New Jersey: John Wiley \& Sons.

Frey, D. (2003). The small business marketing bible. Texas: Marketing Best Practices.

Georgescu, M., \& Popescul, D. (2015). Social media: The new paradigm of collaboration and communication for business environment. Procedia Economics and Finance, 20, 277-282.

Godin, S. (1999). Permission marketing. London: Simon \& Schuster.

Halligan, B., \& Shah, D. (2010). Inbound marketing: Get found using Google, social media, and blogs. New Jersey: John Wiley \& Sons.

Hall-Phillips, A., Park, J., Chung, T.L., Anaza, N.A., \& Rathod, S.R. (2016). I (heart) social ventures: Identification and social media engagement. Journal of Business Research, 69(2), 484-491.

Herring, S.C., Scheidt, L.A., Bonus, S., \& Wright, E. (2004). Bridging the gap: A genre analysis of weblogs. In: Proceedings of theThirty-seventh Hawaii International Conference on System Sciences. Los Alamitos: IEEEPress. HICSS-37.

Hudson, S., Huang, L., Roth, M.S., \& Madden, T.J. (2015). The influence of social media interactions on consumer-brand relationships: A three-country study of brand perceptions and marketing behaviors. International Journal of Research in Marketing, 15. in Press, Corrected Proof, Available online 15 July.

Hussain, T. (2009). Integration with other media. Mobile advertising handbook. London: Internet Advertising Bureu (IAB).

Kaplan, A.M., \& Haenlein, M. (2010). Users of the world, unite!, The challenges and Serious!, Understanding the Functional Building Blocks of Social Media. Business Horizons, 54(3), 241-251.

Kietzmann, J.H., Hermkens, K., Mccarthy, I.P., \& Silvestre, B.B. (2011). Social media?, Get serious!, Understanding the functional building blocks of social media. Business Horizons, 54, 241-251.

Kotler, F., \& Keller, K.L. (2009). Marketing management. New Jersey: Pearson Prentice Hall..

Kotler, P. (2002). Marketing management. Pearson Custom Publishing. Millenium Edition.

Lalić, D. (2010). Socijalne mreže u funkciji unapređenja internih odnosa sa javnošću. Fakultet tehničkih nauka, Univerzitet u Novom Sadu.

Latinović, B., Jotanović, G., Jauševac, G., \& Majkić, M. (2007). Marketing na internetu. Infoteh, Jahorina, 6, 311-315. Ref. E-I-12.

Lincoln, S. (2009). Mastering Web 2.0: Transform your business using key Website and social media tools. London: Kogan Page.

Mangold, W.G., \& Faulds, D.J. (2009). Social media: The new hybrid element of the promotion mix. Business Horizons, 52(4), 357-365.

Maresh-Fuehrer, M.M., \& Smith, R. (2016). Social media mapping innovations for crisis prevention, response, and evaluation. Computers in Human Behavior, 54, 620-629.

Masmi, (2012). Korišćenje društvenih mreža u kompanijama. Retrieved from www.masmi.rs 
Veselinović T. et al.: Is There a Correlation Between Organizational Features and...

Mulhern, F. (2009). Integrated marketing communications: From media channels to digital connectivity. Journal of Marketing Communications, 15(2/3), 85-101.

Author, (2013).

Paulter, S. (2011). End of the credit card?, With one swipe of an iPhone you'll be able to pay for your shopping. London: Daily Mail.

Puška, A. (2012). Alati za izvođenje marketing aktivnosti putem socijalnih mreža. Praktični menadžment, 3(4), 75-80.

Safko, J., \& Brake, D.K. (2009). The Social Media Bible: Tactics, Tools, and Strategies for Business Success. New Jersey: John Wiley \& Sons.

Scoble, R., \& Israel, S. (2006). Naked conversations: How blogs are changing the way businesses talk with customers. New Jersey: John Wiley \& Sons In..

Scott, D.M. (2009). The new rules of marketing and PR. New Jersey: John Wiley \& Sons, Inc..

-Statistical Office of the Republic of Serbia. (2015). Upotreba informaciono komunikacionih tehnologija u Republici Srbiji. Retrieved from http://webrzs.stat.gov.rs/WebSite/repository/documents/00/01/85/78/ICT2015s.p df

Šiđanin, I. (2012). Menadžment socijalnih medija i medijsko okruženje. Škola biznisa, 4, 17-23.

Stelzner, M. (2015). Social media marketing industry report, Social Media Examiner. Retrieved from http://www.socialmediaexaminer.com/social-media-marketingindustry-report-2015/

Stelzner, M. (2014). Industry report: How marketars are using social media to grow, Social Media Examiner. Retrieved from http://www.socialmediaexaminer.com/social-media-marketing-industry-report2014/

Sudarević, T. (2011). Viralni marketing u sklopu Web 2.0 marketing strategije. In N. Janićijević \& S. Lovreta (Eds.), Novi metodi menadžmenta i marketinga u podizanju konkurentnosti srpske privrede. (pp. 191-203). Beograd: Centar za izdavačku delatnost Ekonomski fakultet Beograd.

Tate, M.A. (2010). Web wisdom: How to evaluate and create information quality on the Web. Florida: Taylor \& Francis Group.

-TechnoratiMedia. (2013). Digital influece report. Retrieved from http://technorati.com/report/2013-dir/

Thomas, L. (2011). The McGraw-Hill 36-Hour Course: Online Marketing. New York: McGraw-Hill.

Tiago, M.T.P.M.B., \& Verissimo, J.M.C. (2014). Digital marketing and social media: Why bother?. Business Horizons, 57(6), 703-708.

Author, (2015). .

Vučinić, S. (2015). Strategije komunikacije u kriznim situacijama. Beograd: Čigoja štampa.

Weber, L. (2009). Marketing to the social web: How digital customer communities build your business. New Jersey: John Wiley \& Sons.

Weil, D. (2006). The corporate blogging book. New York: Portfolio Penguin Group.

Yadav, M., Joshib, Y., \& Rahmanc, Z. (2015). Mobile social media: The new hybrid element of digital marketing communications. Procedia - Social and Behavioral Sciences, 189,

335-343. 
